九州大学学術情報リポジトリ

Kyushu University Institutional Repository

Strategic Project Planning Solution Model in The Radioactive Minerals Processing Pilot Plant Construction

Madyaningarum, Nunik

Nuc lear Minerals Technology, JI.

Berawi, Ali, Mohammed

Faculty of Engineering, Jl.

Yarianto Sugeng Budi Susilo

Nuclear Minerals Technology, JI.

https://doi.org/10.5109/2740941

出版情報: Evergreen. 7 (1)，pp.51-55，2020-03. 九州大学グリーンテクノロジー研究教育センター バージョン：

権利関係 : 


\title{
Strategic Project Planning Solution Model in The Radioactive Minerals Processing Pilot Plant Construction
}

\author{
Nunik Madyaningarum ${ }^{1}$, Mohammed Ali Berawi, ${ }^{2, *}$, Yarianto Sugeng Budi Susilo ${ }^{1}$ \\ ${ }^{1}$ Nuclear Minerals Technology, Jl. Lebak bulus raya no9,pasar jumat, Jakarta and 12440, Indonesia \\ ${ }^{2}$ Faculty of Engineering, Jl. Margonda Raya, Beji, Pondok Cina, Depok and 16424, Indonesia \\ *Author to whom correspondence should be addressed: \\ E-mail: $\underline{\text { maberawi@eng.ui.ac.id }}$
}

(Received October 31, 2019; Revised January 27, 2020; accepted February 24, 2020).

\begin{abstract}
Determining strategic solution for improving quality which has an impact on increasing safety factor is the aim of this research. Therefore, planning on a construction project must be a bridge that links between the process improvement, priorities that support success, and the organization's long-term strategy. This study uses literature study approach that focuses on nuclear facilities and other energy projects which further explain the elements of project planning factors in the construction phase. Brief interviews to experts have been conducted as a validation tool. The main factors for strategic project planning are risk management, modularization, technological uniqueness, project typology and governance.
\end{abstract}

Keywords: evergreen; project planning, radioactive minerals, pilot plant, construction

\section{Introduction}

Leadership and commitment, project planning, and safety culture are factors that dominantly affect the construction quality of radioactive minerals processing pilot plant ${ }^{1}$. Construction quality improvement is a successful implementation of quality management systems. The quality of construction that provides a safety factor in the construction of a pilot plant of nuclear fuel processing is affected by monitoring and supervision $^{1)}$. Strategic planning is important to be understood in order to attain project excellence. The reason is because quality management system is the main issue to achieve the integration of quality values, purpose and practice of the project success ${ }^{2}$. Besides, quality management for conformance to specification challenges the organization to improve continuous quality in number of critical inputs, process and output ${ }^{3)}$. Those factors are the basic need to achieve Project Quality, and then Quality Projects firmly establish project excellence with exogenous factors namely the concept of operational excellence and Self-Assessment ${ }^{4)}$. Good planning in scheduling and cost projection is the powerhouse needed to achieve high quality product ${ }^{5}$.

Adequate energy supply at reasonable prices is necessary for the people's live, economic and industrial activities of the country ${ }^{6}$. Indonesia's nuclear industry is currently facing an increasing need for nuclear fuel and requires an increase in mineral separation technology - such minerals of the host rock. In response, the strategic planning of nuclear facilities construction must fulfil safety requirements, including those specified in IAEA safety standards ${ }^{7}$. Nuclear facility is a complex infrastructure. The normative planning process at the construction large and complicated project technically consists of five phases, as follows, preparing planning process, gathering information, creating the plan, disseminating information, and evaluating the planning process ${ }^{2)}$.

Construction is a project based industry which means the definition of quality in the construction is by fulfilling the customer's expectation ${ }^{8)}$. Therefore, strategic planning on a construction project should be a bridge that links the process improvement, with priorities that support success and the organization's long-term strategy ${ }^{9}$. In the other words, integrating a strategic plan involves efforts to balance the needs of stakeholders such as clients, developers, users and the community, integrating the roles and responsibilities of many parties, and linking customer quality expectations with specific objectives and processes throughout the design and construction phases ${ }^{10)}$. For developing construction company, planning is a procedure, a detailed manual standard planning steps about who does what, when and how ${ }^{11)}$. In most construction companies conducting formal planning, the primary focus is on time planning, and as well as to a lesser extent on resource allocation and its cash-flow implications. They key issue of how to carry out the work (i.e. the method statement) does not receive due attention ${ }^{12)}$.

Several previous studies claimed that planning is one 
of the dominant factors of the project quality. It is an integration of quality plan ${ }^{13)}$, planning in program ${ }^{14)}$, organizational resources ${ }^{15)}$, internal procedures ${ }^{16)}$ and project planning ${ }^{1)}$. In addition to it, there are several further studies related to strategic planning, namely characteristic, focus and process ${ }^{12)}$, role ${ }^{12), 2)}$, and relationship between strategic planning and project excellence ${ }^{17)}$.

Project planning in an organization and also in a system has been most of the time topic in the previous studies. No study has ever discussed about a model of project planning for radioactive minerals processing facility yet. This model is expected to be a solution for future development of the processing facility particularly in improving construction quality that provides a safety factor. This research addresses the gap with a literature review approach and interviews with experts involved in this field.

\section{Methodology}

This paper uses literature study approach. A reviewer, for instance, might show a bias by omitting or neglecting some portions of the literature because of his or her preferences or mistakes ${ }^{18)}$. The data analysis used deep analysis i.e. literature review. The advantage of the literature review is that a researcher can examine the state of knowledge of a specific topic 19)20)21). The specific topic of this paper is project planning for a radioactive minerals processing facility. The literature study has been conducted on case studies of nuclear facilities projects and other energy projects that explain the elements of project planning factors in the construction phase. Then the results of this literature review are elaborated to be more specific for a radioactive minerals processing facility with experts' opinions. The experts in this study have the requisite work experience of at least ten (10) years and are the experts on safety, project planning, technology auditing for nuclear energy technology.

The strategic project planning consists of several supporting sub-factors which have several activities that can be done. The risk management is one of the sub-factors, as conducted in Poland using IRDM (integrated risk informed decision making) with the Value Tree analysis questionnaire model ${ }^{22)}$. In China's construction project, the risk management is carried out with 6 (six) steps in the process, i.e. step 1: risk assessment, step 2: Response options; step 3: control, step 4: forewarning, step5: communication, step 6: supervision and report ${ }^{23)}$.

The second sub-factor is the generator modulation model. Performance improvement for infrastructure projects through modularization has been carried out over the past few years. There are two types of modularization including one factory with a dependent module, which is a the manufacturing process of the manufacturing module where the delivery and installation process in the field contains complete assemblies (i.e. modern large power plants such as $\mathrm{AP} 1000)^{24)}$, and modular unit (many factories with independent modules), which is a factory for producing some modules that can be used independently (for example Small Modular Reactors like Nuscale) ${ }^{25), 26)}$.

The third sub-factor is project typology. The project typology consists of year, geographical location, cost and construction time 25),27). The next sub-factor is uniqueness of technology. Poor performances in planning and constructing power plants have been frequently associated with FOAK (first-of-a-kind) technologies 28),29). The design must be mature and the licensed problem is resolved before the start of construction ${ }^{30)}$.

The last sub-factor is project governance. The literature considers that "project governance" as one of the key aspects in the delivery of megaprojects ${ }^{31)}$. There are some forms of project governance i.e. partnership, corporate partnership/joint venture, project joint venture, public private partnership (PPP), consortium ${ }^{31)}$ and the existence of SPV (special purpose vehicle) or SPE (special purpose entity) $^{32}$. The summary of literature study on project planning factors variables is shown in Table 1.

Table 1. Independent variables in research

\begin{tabular}{|c|c|c|}
\hline No & $\begin{array}{l}\text { Supporting } \\
\text { sub-factors }\end{array}$ & Activity \\
\hline \multirow[t]{2}{*}{1.} & \multirow[t]{2}{*}{$\begin{array}{l}\text { Risk } \\
\text { Management }\end{array}$} & $\begin{array}{l}\text { IRDM (integrated risk informed } \\
\text { decision making) with the Value Tree } \\
\text { analysis questionnaire model }\end{array}$ \\
\hline & & $\begin{array}{l}6 \text { (six) steps in the process, i.e. Step 1: } \\
\text { risk assessment, step 2: Response } \\
\text { options; step 3: control, step 4: } \\
\text { forewarning, step 5: communication, } \\
\text { step 6: supervision and report }\end{array}$ \\
\hline \multirow[t]{2}{*}{2} & \multirow{2}{*}{$\begin{array}{l}\text { Plant } \\
\text { Modulation } \\
\text { Model }\end{array}$} & a single plant with dependent module \\
\hline & & $\begin{array}{l}\text { Modular unit (many plant with } \\
\text { independent modules) }\end{array}$ \\
\hline 3 & $\begin{array}{l}\text { Project } \\
\text { Typology }\end{array}$ & $\begin{array}{l}\text { - } \text { year } \\
\text { - geographical location } \\
\text { - cost and construction time }\end{array}$ \\
\hline \multirow[t]{2}{*}{4} & \multirow{2}{*}{$\begin{array}{l}\text { Uniqueness } \\
\text { of } \\
\text { Technology }\end{array}$} & $\begin{array}{l}\text { Use of existing types of technology; } \\
\text { avoid using FOKT (first of kind tech.) }\end{array}$ \\
\hline & & $\begin{array}{l}\text { The design must be mature and the } \\
\text { licensing problem is resolved before } \\
\text { the start of construction }\end{array}$ \\
\hline 5. & $\begin{array}{l}\text { Project } \\
\text { Governance }\end{array}$ & $\begin{array}{l}\text { - Partnership } \\
\text { - Corporate partnership/joint venture } \\
\text { - Project joint venture } \\
\text { - Public Private partnership (PPP) } \\
\text { - Consortium }\end{array}$ \\
\hline
\end{tabular}

Those 5 (five) supporting sub-factors and 15 variables are used to answer research question on what model of project planning suitable for a radioactive minerals processing facility that can be a solution. 


\section{Result and Discussion}

The previous study showed that the regression coefficient $(\mathrm{R})$ of the dominant factors is 0.930 . This means that $92.3 \%$ of the factors affecting the achievement of the construction quality of the pilot plants are rarely determined by leadership and commitment, project planning, and safety culture ${ }^{1)}$. The value of project planning was $-0.616^{1}$.

According to the results of the project planning literature study for the solution model, there were 5 (five) sub-factors and 15 (fifteen) activities shown in Table 1. Furthermore, based on the case study (a radioactive minerals processing facility), the initial solution model is produced with 5 (five) sub-factors and 9 (nine) activities (Fig.1). The six activities are considered irrelevant to the construction of the pilot plant.

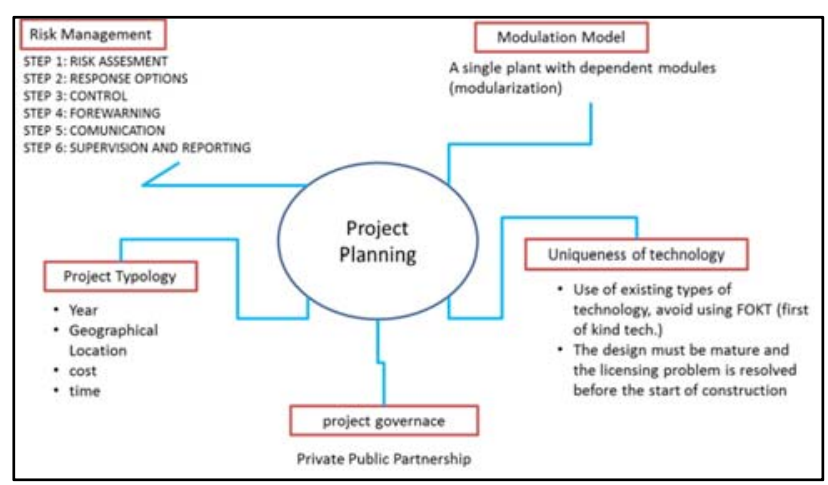

Fig. 1: The initial model solution for Project planning

Interviews with the experts are carried out in order to validate the initial solution model of project planning factors. $75 \%$ of the experts hold a master's degree and $25 \%$ hold a doctoral degree. In the first sub-factor, $80 \%$ of the experts acknowledged risk management without reservation, and the other $20 \%$ agreed with notes. These experts added corrective actions to the activities in the step 5 of the risk management sub-factor. $100 \%$ of the experts have agreed to add Domestic Component Level activity in the project typology sub-factor. $80 \%$ of the experts have agreed that modulation model with each sub-system or sub system module can reduce the risk of function, cost and time. For the uniqueness of technology sub-factor, $100 \%$ of the experts agreed without notes. The summary of experts' comments on the model of the initial solution of project planning factors can be seen in Fig. 2 and the quantitative summary of the experts' answers is shown in Fig. 3.

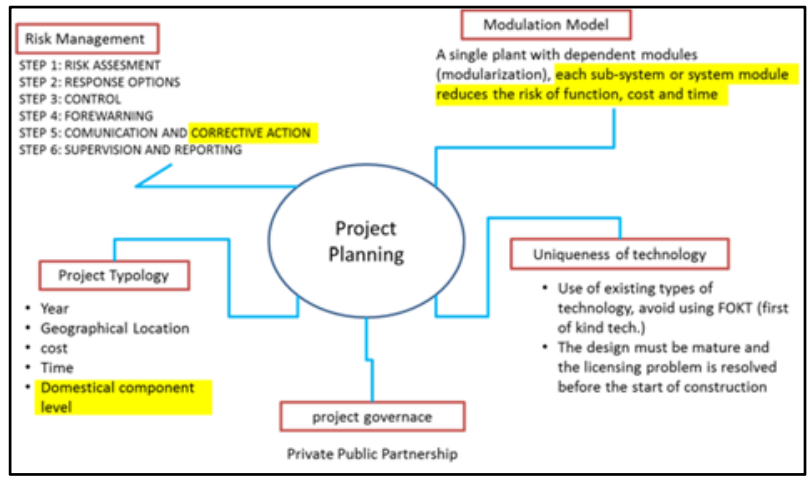

Fig. 2: The validated project planning solutions model

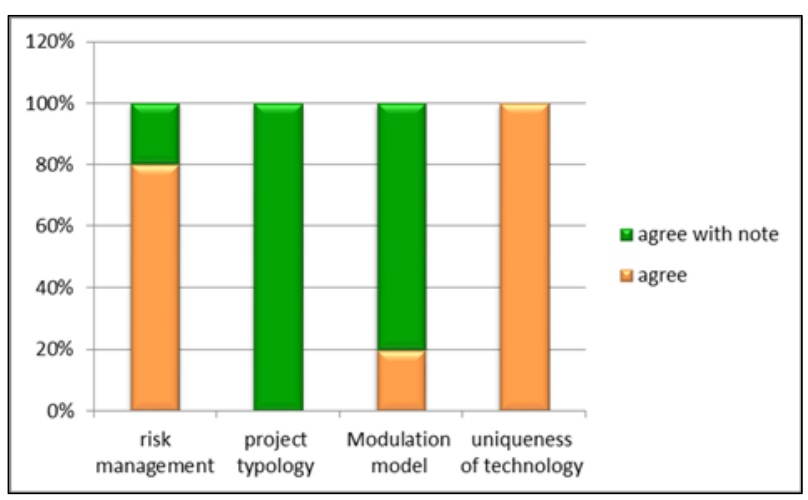

Fig. 3: The quantitative summary

Risk management is carried out to anticipate the risks that might occur in the construction of the pilot plant by identifying the risk response as well as continuing the supervision and communication between stakeholders and conducted corrective actions. All of these activities are summarized in a risk management report in the construction of the pilot plant and are used as a database for learning (lesson learned) for the next construction of nuclear facilities. The pilot plant modularization system is a free module system or individual module on each system and sub-system, hence reducing function, time and cost risks ${ }^{25)}$. In terms of technological uniqueness, this pilot plant does not use first of kind technology (FOKT) as in China (The Royal Academy of Engineering, 2010), the technology used has reliability proven and the licensing process has been completed before the construction phase such as in China, French and English ${ }^{30)}$.

The project typology sub-factor is characterized by the year built, geographical location, cost and time of construction ${ }^{27)}$, the results of the interview with the experts added the domestic component level (TKDN) as one of the characteristics. The pilot plant for processing uranium, thorium and rare earth metals was built in 2016 in Indonesia, where processing technology at the laboratory level has been mastered ${ }^{7)}$. It is located in Pasar Jumat area in South Jakarta, particularly at the Center for Nuclear Minerals Technology - National Nuclear Energy Agency (BATAN), where access to the 
pilot plant can be easily traversed by transportation modes used to construct equipment and materials. The level of use of domestic components (TKDN) in the pilot plant construction has been required in the auction document ${ }^{33)}$. The construction time of the pilot plant is 240 calendar days since the kick-off meeting was held on April 17, 2016. The cost for the construction of the pilot plant is taken into account by involving various parties to obtain the calculation in accordance with the need for the construction of a pilot plant.

Center for Nuclear Minerals Technology regulated the project management and worked with construction companies that won the auction process as well as with new organizations that make it possible for things to go wrong during the construction process. Therefore, the reason to conduct the assessment of the pilot plant project planning for the separation of Uranium, Thorium and Rare Earth is rarely carried out through comparison of ideal conditions in accordance with the above model with the real conditions of project planning, including the organizational structure, communication lines, supervisory functions, and command lines. Some of strategies that can be done to anticipate problems are that we should review the contractors' project documents thoroughly, give comment to unclear organizational structure, command flow and communication, conduct the daily, weekly, and monthly meeting to understand the project progress, construction supervisor competency training, and last but not least is to establish the same vision and mission for the project between the supervisor and project owner.

\section{Conclusion}

The solution model composed by sub-factors and the specific activities greatly affect the achievement of construction quality. A validated solution model application provides an overview of project planning conditions at the pilot plant. The result model provides an understanding that increasing project planning factors in achieving pilot construction quality of processing Uranium, Thorium and Rare Earth Metals processing is influenced by risk management, modularization model, technological uniqueness, project typology and project governance. The solutions generated from this research are useful in determining strategies for improving the construction quality which have an impact on increasing safety factors. However, the effectiveness of the main factors and its activities still need to be monitored and measured.

\section{Acknowledgements}

The authors would like to thank all the parties that have participated in this research. Especially, Center for Nuclear Minerals Technology for granting research permits and University of Indonesia for the publication grant.

\section{References}

1) N. Madyaningarum, M. Ali Berawi, Gunawan, and I.G. Sukadana, "Dominant factors influencing project quality in the radioactive minerals processing pilot plant construction," MATEC Web Conf., 276 02005

doi:10.1051/matecconf/201927602005.

2) E. Suarez, A. Calvo-Mora, and J.L. Roldán, "The role of strategic planning in excellence management systems,” Eur. J. Oper. Res., 248 (2) 532-542 (2016). doi:10.1016/j.ejor.2015.07.008.

3) M.K. Barai, S.K. Bala, Y. Suzuki, and B.B. Saha, "Higher education in private universities in bangladesh: a model for quality assurance," Evergreen, 2 (2) 24-33 (2015).

4) R. Basu, "Managing quality in projects: an empirical study," Int. J. Proj. Manag., 32 (1) 178-187 (2014). doi:10.1016/j.ijproman.2013.02.003.

5) M. abdur rahman, H; ali berawi, "Quality assurance : good practice, regulation, and law ' power quality system ,' a new system of quality management for globalization : towards innovation," (January 2015) 37-41 (n.d.). doi:10.1080/713843985.

6) M.K. Barai, and B.B. Saha, "Energy security and sustainability in japan," Evergreen, 2 (1) 49-56 (2015).

7) PTBGN-BATAN, "Terms of Reference for the Separation of Prototype Pilot Factories from Uranium, Thorium and Rare Earth from Monasite" 2016.

8) K.N. Jha, and K.C. Iyer, "Critical factors affecting quality performance in construction projects," Total Qual. Manag. Bus. Excell., 17 (9) 1155-1170 (2006). doi:10.1080/14783360600750444.

9) S. Rao, and T.J. Goldsby, "Supply chain risks: A review and typology," 2009. doi:10.1108/09574090910954864.

10) M. M. Toakley, A. R., "Towards total project quality-a review of research needs," eng. constr. archit. manag.," Eng. Constr. Arch. Manag., 10 (3) 219-228 (2003).

11) W. M. Lindsay and and L. W. Rue, "'Impact of the organization environment on the longrange planning process: a contingency view," Acad. Manag. J., 23 (3) 385-404 (n.d.).

12) A.L.R. Tucker, "Is construction planning really doing its job? a critical examination of focus, role and process. construction management and economics," (June 2013) 37-41 (1987).

13) A. Mat Naim, M. Abdul Hakim, J.L.Y. Mei, and L.S. Ting, "Critical succes factors of project quality management system for malaysian construction industry," J. Teknol., 74 (2) 123-131 (2015). doi:10.11113/jt.v74.4532.

14) T. Elghamrawy, and T. Shibayama, "Total quality management implementation in the egyptian construction industry" J. Manag. Eng., 24 (3) 156- 
161 doi:10.1061/(ASCE)0742-597X(2008)24:3(156)

15) D. Kim, V. Kumar, and U. Kumar, "A performance realization framework for implementing iso 9000," Int. J. Qual. Reliab. Manag., 28 (4) 383-404 (2011). doi:10.1108/02656711111121807.

16) C. V. Fotopoulos, and E.L. Psomas, "The structural relationships between tqm factors and organizational performance," TQM J., 22 (5) 539-552 (2010). doi:10.1108/17542731011072874.

17) T.R. Dvir, Dov, and A.J. Shenhar, "An empirical analysis of the relationship between project planning and project success," 7863 (FEBRUARY) 89-95 (2003). doi:10.1016/S0263-7863(02)00012-1.

18) T.D. Stanley, "Wheat from chaff: meta-analysis as quantitative literature review," 15 (3) 131-150 (2001).

19) R.E. Baumeister, and M.R. Leary, "Writing narrative literature reviews," 1 (3) 311-320 (1997).

20) M.A. Berawi, B.E. Ibrahim, Gunawan, and P. Miraj, "Developing a conceptual design of transit-oriented development to improve urban land use planning," $J$. Des. Built Environ., 19 (1) 40-48 (2019).

21) M.A. Berawi, B. Susantono, P. Miraj, and F. Nurmadinah, "Prioritizing airport development plan to optimize financial feasibility," Aviation, 22 (3) 115-128 (2018). doi:10.3846/aviation.2018.6589.

22) M. Borysiewicz, K. Kowal, and S. Potempski, “An application of the value tree analysis methodology within the integrated risk informed decision making for the nuclear facilities," Reliab. Eng. Syst. Saf., 139 113-119 doi:10.1016/j.ress.2015.02.013.

(2015).

23) L. Jiang, Chen CHINERGY CO., "No Title," 2017.

24) R.A. Matzie, "AP1000 will meet the challenges of near-term deployment," Nucl. Eng. Des., 238 (8) 1856-1862

(2008). doi:10.1016/j.nucengdes.2007.10.035.

25) N.J. Brookes, and G. Locatelli, "Power plants as megaprojects: using empirics to shape policy, planning, and construction management," Util. Policy, $36 \quad 57-66 \quad$ (2015). doi:10.1016/j.jup.2015.09.005.

26) World Nuclear Association, "Small nuclear power reactors," (2018).

27) B.K. Sovacool, A. Gilbert, and D. Nugent, "Risk , innovation , electricity infrastructure and construction cost overruns : testing six hypotheses," 74 906-917 doi:10.1016/j.energy.2014.07.070.

28) D. Finon, and F. Roques, "Financing arrangements and industrial organisation for new nuclear build in electricity markets," (March 2008) (2008).

29) A.C. Levitt, W. Kempton, A.P. Smith, W. Musial, and J. Firestone, "Pricing offshore wind power," Energy Policy, 39 (10) 6408-6421 (2011). doi:10.1016/j.enpol.2011.07.044.
30) The Royal Academy of Engineering, "Nuclear Lessons Learned," 2010.

31) I. Ruuska, T. Ahola, K. Artto, G. Locatelli, and M. Mancini, "A new governance approach for multi-firm projects: lessons from olkiluoto 3 and flamanville 3 nuclear power plant projects," Int. J. Proj. Manag., $29 \quad$ (6) 647-660 (2011). doi:10.1016/j.ijproman.2010.10.001.

32) T. Sainati, N. Brookes, and G. Locatelli, "Special purpose entities in megaprojects : empty boxes or," $48 \quad$ (2) $\quad 55-73 \quad$ (2017). doi:10.1177/875697281704800205.

33) BATAN, "Electronic Procurement Document for Construction of Prototype Pilot Plant for Uranium, Thorium and Rare Earth Metal Separation, Center for Minerals Technology 2016," 2016. 